\title{
REVIEW OF TECHNOGENIC WASTE AND METHODS OF ITS PROCESSING FOR THE PURPOSE OF COMPLEX UTILIZATION OF TAILINGS FROM THE ENRICHMENT OF NON-FERROUS METAL ORES AS A COMPONENT OF THE RAW MATERIAL MIXTURE IN THE PRODUCTION OF CEMENT CLINKER
}

\author{
A.S. Kolesnikov ${ }^{1}$, B. Ye Zhakipbaev ${ }^{1,2}$, N.N. Zhanikulov ${ }^{1}$, \\ O.G. Kolesnikova ${ }^{1, \bowtie}$, E.K. Akhmetova ${ }^{1}$, R.M. Kuraev ${ }^{1}$ and A.L. Shal ${ }^{1}$ \\ ${ }^{1}$ Department of Safety of Ability to Live and Environment Protection, M. Auezov South \\ Kazakhstan University, 160012, (Shymkent) Kazakhstan \\ ${ }^{2}$ Department Science and Innovation, Silkway International University, 160000, \\ (Shymkent) Kazakhstan \\ ${ }^{\square}$ Corresponding Author: kas164@yandex.kz
}

\begin{abstract}
This article presents the results of studies of an analytical review of the possibility of using tailings from the beneficiation of the Balkhash concentration plant as a component of the raw mixture for producing cement clinker. In particular, an analytical review of research was carried out, where the issues of the formation of man-made mineral objects of industrial waste in the Republic of Kazakhstan were considered. The information on the tailings as a large-tonnage man-made waste from the mining and processing and metallurgical industries is presented. The utilization of waste from the beneficiation of non-ferrous metal ores is considered, the characteristics of the beneficiation tailings of the Balkhash beneficiation plant are given, the processes of obtaining Portland cement clinker and its phase compositions are considered.
\end{abstract}

Keywords: Tailings, Non-ferrous Metals, Cement Clinker, Metallurgical Industries, Portland Cement.

RASĀYAN J. Chem., Vol. 14, No.2, 2021

\section{INTRODUCTION}

One of the first places among building materials is occupied by binders, and mainly cement. Today cement is the "bread" of construction and there is no limit to its use. Today, several special types of cement of one or another chemical and mineral composition are produced, designed to achieve a specific goal in the technology of various building materials and structures. In particular, for the implementation of the state program "Affordable Housing 2020", today, within the framework of another state program of Industrial and Innovative Development 2, much attention is paid to the chemical industry, including the cement industry, since it is this industry that will contribute to the implementation of the program for affordable housing, providing construction process with cement. ${ }^{1}$

Serious attention is paid to improving the quality of cement. It is necessary to increase its average grade, as well as to increase the production of several special types of cement. An effective way to save energy in the production of Portland cement clinker is to optimize the composition of the raw mix according to modular characteristics and saturation coefficient. An example of such optimization is the production of low-basic clinkers with strength characteristics that are not inferior to highly basic ones while maintaining the original raw material base with the involvement of technogenic mineral formations. The production of low-basic clinker saves fuel and raw materials and reduces the harmful effect on the environmental situation.It is known that the main resources in the production of binders were previously provided by traditional mineral raw materials. In the new economic realities, this approach is qualitatively changing, and industrial wastes act as secondary raw materials. ${ }^{2-6}$ The cost of such raw materials is much lower, and 
the processing conditions are often simple. These features of economic development insistently require a qualitative study of all types of accumulated and unused and waste.

One of such wastes is waste from the mining and processing and metallurgical industries - tailings from the Balkhash concentration plant, ${ }^{7,8}$ which contain in their chemical composition several useful compounds, in particular, silicon, aluminum and iron oxides, which are necessary to obtain cement clinker.

Thus, research and scientific work aimed at reducing energy costs and unit costs of raw materials, involving man-made raw materials in the production cycle with an accompanying reduction of the harmful impact on the environment due to their utilization when obtaining cement clinker are relevant.

\section{Analysis of Industrial Waste Generation in Kazakhstan}

Analysis of several information sources has shown that in Kazakhstan, the generalization of information on man-made mineral waste (MMW) has been conducted since the beginning of the 80 -ies of the last century. One of the first cadastres "Cadaster of resources and prospects for the integrated use of nonferrous metallurgy waste in Kazakhstan" and "Cadaster of resources and prospects for the integrated use of ores and ferrous metallurgy waste" were developed by the Council for the study of production forces at the Academy of Sciences of the Kazakh SSR in 1986 and 1989.9,10

According to various data Of the Committee of Geology and subsoil use of the Ministry of industry and trade, as of 01.01.2011, the Cadastre includes an information order for 906 objects (dumps, tailings dumps and various storage facilities of mining enterprises of the Republic of Kazakhstan) with the volume of solid mineral waste stored on an area of $611 \mathrm{~km}^{2}-36.2$ billion tons the Ministry at that time found that the largest volume of MMW (more than 5.0 billion tons) accumulated in the trade of regions where the mining, processing and metallurgical industries are developed (in particular, the Karaganda region, Pavlodar region, East Kazakhstan region,). a small amount of solid mineral waste is accumulated in the Kyzylorda region and Mangystau (slightly less than 1.0 million tons). By placing solid mineral waste in quantitative terms, the leading regions are East Kazakhstan-247 objects, Karaganda-225 objects and Aktobe-147 different MMW objects. The content of the lowest amount of MMW is in Mangystau and West Kazakhstan and Kyzylorda regions (6.5 and 1.0 respectively). ${ }^{11}$

Among the numerous MMW objects, we took into account objects that were formed before 30.05.1992, according to the law of the Republic of Kazakhstan "On subsoil and subsoil use"), after it, as well as MMW formed before the specified date and the process of formation, was completed after, or continues to the present time. That is, at the moment, the legal norm for solid mineral waste is defined as state ownership (if the waste is accumulated before the specified period), a mixed form - private enterprises or organizations store items at enterprises or facilities that are in operation at the time of privatization (tailings, ash sludge in the form of storage facilities and dumps), and private - this enterprise (organization) stores tmos at newly built and or in specially designated storage and placement areas. To determine one or another part of the share of MMW in a mixed type of ownership, it is necessary to implement a dividing balance. The basis for implementing a separation balance at such facilities is to involve them in recycling or in determining the number of further directions for their comprehensive disposal to reduce the impact on the environment. At the moment, the law of the Republic of Kazakhstan "on subsoil and subsurface use" considers solid mineral waste as equal subjects and objects of mineral raw materials, while taking into account their practically aggravating impact on the environment to the least extent.

Thus, assigning responsibilities only to business structures will not help solve the environmental problems of the regions. The state cadastre of mineral technogenic waste formations counts and is subject to accounting 202 objects of waste formations that undoubtedly belong to the category of "solid mineral formations in state ownership", that is, these are those wastes that were formed before 30.05.1992. Their stored quantity by region is shown in Table-1.,11

As can be seen from the above data, 67 objects are represented by various overburden dumps, and 23 objects are tailings dumps of processing plants, which can be in demand as raw materials for the silicate and construction industries. 
RASĀYAN J. Chem.

Vol. 14 | No. 2 |997-1005| April - June | 2021

Table-1: Technogenic Mineral Waste Products related to State Property ${ }^{11}$

\begin{tabular}{|c|c|c|c|c|c|}
\hline \multirow[t]{2}{*}{ Administrative Region } & \multicolumn{4}{|c|}{ Types of technogenic mineral formations } & \multirow{2}{*}{$\begin{array}{l}\text { In the } \\
\text { Whole } \\
\text { Region }\end{array}$} \\
\hline & $\begin{array}{c}\text { Dumps } \\
\text { Breeds } \\
\text { Autopsies }\end{array}$ & $\begin{array}{c}\text { Off-balance Sheet } \\
\text { and substandard Ore } \\
\text { Dumps }\end{array}$ & $\begin{array}{c}\text { Tailing Dumps } \\
\text { Processing Plants }\end{array}$ & $\begin{array}{c}\text { Slags } \\
\text { Metallurgical Plants } \\
\text { and Ash Dumps }\end{array}$ & \\
\hline Akmolinsk & 5 & 3 & 4 & 0 & 12 \\
\hline Aktobe & 9 & 56 & 0 & 0 & 65 \\
\hline Almaty & 6 & 0 & 2 & 0 & 8 \\
\hline Atyrau & 10 & 9 & 0 & 0 & 19 \\
\hline East- Kazakhstan & 14 & 7 & 7 & 1 & 29 \\
\hline Zhambyl & 3 & 20 & 1 & 0 & 24 \\
\hline West Kazakhstan & 0 & 0 & 0 & 0 & 0 \\
\hline Karaganda & 6 & 9 & 4 & 0 & 19 \\
\hline Kostanay & 5 & 1 & 2 & 0 & 8 \\
\hline Kyzylorda & 1 & 0 & 0 & 0 & 1 \\
\hline Mangystau & 0 & 0 & 0 & 0 & 0 \\
\hline Pavlodar & 2 & 1 & 0 & 0 & 3 \\
\hline North- Kazakhstan & 6 & 3 & 0 & 0 & 9 \\
\hline Turkistan & 0 & 1 & 3 & 1 & 5 \\
\hline TOTAL & 67 & 110 & 23 & 2 & 202 \\
\hline
\end{tabular}

The result of the work of factories that process various ores, including copper-zinc ores, is the formation of production waste on the earth's surface on the territory of the enterprise or in the vicinity of it. The reason for such formations is a rather low content of non-ferrous metals in them and a decrease in the quality of processed ores. Natural leaching of stored formations of various types of material through dust formation and migration of waste compounds and particles to underground and surface waters leads to a violation of the ecological balance in the natural environment. The annual gradual filling of tailing dumps with ore processing products and the concentration of silicon, aluminum, calcium, and iron oxides in them makes it possible to consider tailing dumps as technogenic secondary raw materials for several industries. ${ }^{12}$

According to statistics, non-ferrous metallurgy is in third place in the list of the largest producers of waste generation (by volume). This is due to the multicomponent composition of non-ferrous metal ores and sometimes the low content of useful components in them. As of today, the total share of overburden undergoing recycling and processing is no more than $18 \%$, and the share of waste from enrichment is just over $7 \%$. At the same time, the utilization of metallurgical slags has an insignificant share. ${ }^{2,3}$

Almost $95 \%$ of the extracted non-ferrous metal ores are enriched. The cost of mineral raw materials in the non-ferrous metals industry is about $70 \%$ of all production costs for the industry's products. At the same time, the level of integrated use of mineral raw materials in non-ferrous metallurgy belongs to one of the leading industrial sectors of the economy. ${ }^{2,3,13-15}$

An important area of waste utilization in complex processing of ores of non-ferrous metals include the additional extraction of valuable raw materials from waste and by recycling tailings (technogenic deposits), refining a complex kind of pyrite concentrates by removing iron from the doorway non-ferrous metals; the use of waste in the production of products for the chemical and other industries, the use of waste for the production of several non-ferrous metals. ${ }^{2,3,13-17}$

Rational use of dump tailings that are stored, which is associated with significant financial and material costs, including automation and robotization of technological processes ${ }^{16-19}$ and, accordingly, is one of the important problems of complex utilization of non-ferrous metal ores. In the domestic practical experience, technologies with a separate method for processing sand and sludge fractions of enrichment tailings with the recovery of metals from the sand-containing fraction have been more widely developed. An increase in the number of technical indicators of ore enrichment according to the proposed technology is due to the presence and quantity of valuable components in sand-containing fractions and a decrease in the harmful effect of sludge during flotation. ${ }^{2,13-17}$ 


\section{Methods of Processing Technogenic Waste of Industrial Production in the CIS}

Schemes for re-extraction of valuable components from the sand fraction of tailings, which provide for regrinding of Sands to refresh their surface and flotation of minerals, are implemented at Almalyk, Balkhash, Dzhezkazgan, and other processing plants. Developed and implemented scheme of processing of stale tails on Achisayskoe, Kentoushi, Kayraktinsky and Salair factories. ${ }^{3,13,16}$ At the processing plant No. 1 of the Pechenganikel combine, a magnetic flotation scheme was introduced for the recovery of iron components from the sand fraction of the tailings of copper-Nickel ores, which allowed to increase the recovery of nickel and cobalt. Research on the Sorsky Deposit ores has shown that it is possible to additionally obtain pyrite, magnetite and feldspar concentrate and quartz product for the production of building materials. From the ores of the Kaktenkol Deposit, it is additionally possible to obtain feldspar and mica products. ${ }^{2,3,13,16}$

The Uniformed Institute has established the possibility of obtaining pyrite concentrate from the old dumps of the Sibaiskoi, Sredneuralskaya, Krasnouralskaya and Uchalinskaya processing plant. ${ }^{16-22}$

To date, studies have been conducted on the recovery of valuable components from tailings of ore processing and tailings dumps. The principal possibility of additional recovery of valuable components by magnetic-flotation-gravity schemes is established. Additional extraction of valuable components and production of new products is a cost-effective process since up to $50 \%$ of all enrichment costs are spent on crushing, grinding, screening and classification operations. The processing of tailings dumps is widely used in factories in Germany and Great Britain. Czech Republic, Slovakia, USA and Canada. At enrichment of copper - kolchedannyh ores in the copper concentrate is extracted about $60 \%$ of copper in the zinc concentrate $74 \%$ of the zinc and pyrite $-75 \%$ sulfur. ${ }^{2,3}$

The resulting pyrite concentrate is used for sulfuric acid, and the resulting pyrite stubs are practically not used for extracting valuable components and precious metals from SIC. For the processing of pyrite stub, the technology of autogenic melting with the release of oxide melt and zinc sublimates that concentrate rare metals in their composition has been developed. From the oxide melt, copper and precious metals and ferrous melt are chlorinated from sulfur and other impurities. As a result, ferrous slag is obtained, which is more suitable for ferrous metallurgy, and a product containing non-ferrous and precious metals. ${ }^{2,3,13,15}$ Let's consider methods and methods of waste disposal on the example of the Norilsk Mining and metallurgical combine..$^{2,3,22-27}$

The research center of the plant has worked out a variant of additional flotation of the sand part of the dump tailings and flotation of interspersed ores. The scheme provides for pre-enrichment of tailings in a short-cone hydrocyclone with subsequent flotation of the sand fraction. In the resulting flotation concentrate, the Nickel content is approximately equal to the content in the collective concentrate. the results of industrial testing showed the possibility of reducing losses with dump tailings when enriching interspersed Nickel ores by $3.66 \%$, copper, by $1.8 \%$, precious metals by $5.7 \%$.

The tailings of some processing plants are suitable for the production of chemical products and fertilizers. At the Uchalinsk processing plant, tailings from the tailings storage areas with a high sulfur content are sent to the sulfuric acid plants as pyrite concentrate. The tailings of Leninogorsk, Zyryanovsk, Tekeli and other factories can be used for the production of micro fertilizers. Barite concentrate is obtained by flotation from stale tailings of the Maikan, Kentau, and Kairakta processing plants.

From the slags of non-ferrous metallurgy, it is possible to obtain a fertilizer of slag phosphate by fusing with phosphorus-containing components.

Overburden and host rocks, as well as enrichment tailings, are used for the production of building materials. The light lump fraction obtained during pre-processing of ores in heavy media is used for road construction and production of crushed stone after crushing. In addition, it is established that the tailings of enrichment of some factories can be used for the production of silicate bricks, facing tiles, stone casting, building binders, concrete aggregates, and asbestos.

At the Achisay, Dzhezkazgan and other plants, the enrichment tailings are used as a filler for the hydraulic sealing of spaces developed during mining operations. On several mining companies organized by the associated production of rock chippings of various sizes. Crushed stone is used at enterprises for their own needs, as well as shipped by third-party consumers. 
Krasnouralsky copper smelting, Bashkir and mednogorsky copper-sulfur, Gaysky, Uchalinsky, Urupsky mining and processing plants, and degtyarsky ore management use their waste for the production of construction rubble. Thus, in 1986, these enterprises produced more than 2 million $\mathrm{m}^{3}$ of crushed stone.

\section{Methods of Processing Technogenic Industrial Waste in Developed Countries}

In developed countries, in particular, in the United States in the last century, the share of secondary raw materials in the production of non-ferrous metals was copper - $55 \%$, tungsten - $28 \%$, Nickel- $25 \% ; 20 \%$ of all aluminum, $33 \%$ of iron, $50 \%$ of lead and zinc are obtained from industrial waste, etc. In the state of Montana from the dumps of the mine Mandiki containing $0.84 \mathrm{~g} / \mathrm{t}$ gold and $2.8 \mathrm{~g} / \mathrm{t}$ silver, given annually to $2 \mathrm{t}$ of gold and 4 tons of silver, and in Michigan from tailings (copper content is $0.3 \%$ ) is removed $60 \%$ copper. In Canada, $40 \%$ of copper is recovered from waste from copper ore enterprises containing $0.45 \%$ copper, thanks to new enrichment methods (heap acid leaching, pile pyrite and bacterial leaching). In Bulgaria, copper concentrate is produced from waste containing 0.1-0.15\% copper, the cost of which is 3 times lower than when it is obtained from natural raw materials. In South Africa, 3.5 tons of gold and 696 tons of uranium per year are produced from the dumps of gold recovery factories with a gold content of $0.53 \mathrm{~g} / \mathrm{t}$ and $40 \mathrm{~g} / \mathrm{t}$ of uranium. At the same time, the analysis shows that the main method of disposal of newly generated waste continues to be its disposal in landfills owned by enterprises, or pumping contaminated wastewater into underground water sources, so the volume of their accumulation does not decrease. As the best example of managing large-scale waste from mineral processing, we can consider the most modern approach of one of the canadian companies. ${ }^{28}$ The owners of the canadian malartic mine Were the first to face a huge number of difficulties in building a large open-pit gold mine right in the center of Malartic, Quebec, Canada. Osisko has signed an agreement with the government of the province of Quebec to restore an abandoned area East of Malartic, which has become the province's property and requires further environmental measures. Osisko assumes half of the province's financial obligations to restore the area. Tailings from the new mine will be used for recovery. Another important method is the gradual restoration of vegetation until the end of the mine's life. This process was made possible by the use of tailings thickening technology, which allows trees to be planted during the mine development process. Tailings are thickened using thickeners and filter presses. At the same time, water is removed from the waste, and it turns into a mass that can be stacked in layers in the dump. In addition to the possibility of planting vegetation, thickened tailings can significantly reduce water consumption and reduce the size of the dump that remains at the site of development. Thickened tailings reduced the size of the tailings dump. With a production volume of 55000 tons / day, the same size of the tailings dump that was used for production with a volume of 5000 tons/day can be used. In addition, this reduces the toxicity of tailings before being transported to the tailings storage facility. The vegetation restoration program includes a biodiversity study project. Because the area is an abandoned tailings dump, there is no vegetation in it, it is destroyed by wind erosion. Osisko works with experts to help you choose the plant species that are best adapted to your environment. Residents of this area will be able to see the grass cover in 4 years, and not in 15 years. ${ }^{28}$ In the developed industrial countries of the world, the level of use of industrial waste reaches $70-80 \%{ }^{21-27}$

\section{Tailings From the Enrichment of Non-ferrous Metal Ores as Technogenic Secondary Mineral Raw Materials For the Chemical Industry}

For Kazakhstan, Russia and Ukraine, as countries that produce a significant share of all mineral products in the world, the problem of industrial waste disposal is of paramount importance. This is because the current state of the resource bases of many important mining regions and existing enterprises of our countries has deteriorated dramatically in connection with the depletion of reserves, a decrease in their qualitative and economic characteristics, the complication of working conditions as a result of prolonged and intensive use of previously developed fields. At present, many mining enterprises, especially in old, long-developed ore areas, have reached a critically low level of availability of proven reserves, and the reserve of reserves of many types of minerals in the exploited deposits is insufficient. The situation is compounded by the fact that for most types of minerals, there is a significant curtailment of geological 
exploration. This trend is indicated in the Concept of development of the geological industry of Kazakhstan until $2030 .{ }^{29}$ It is noted that the reserves of non-ferrous and precious metals, which currently make up a significant share of exports, are limited and can be worked out in 12-15 years. At the same time, this document does not show a significant rate for replenishment of the mineral resource base at the expense of TMO. The mass of waste accumulated in dumps and tailings dumps with an average layer thickness of $20 \mathrm{~m}$ covers an area of more than $1300 \mathrm{~km}^{2}$. The annual increase in the area of alienated land is at least $85-90 \mathrm{~km}^{2}$. The negative impact on the environment is manifested in an area that is 10 times or larger than the area occupied by waste. A significant part of the land being alienated is located in industrially developed areas, often within the borders of localities and large cities. But at that time, tmos are used only as raw materials for the construction industry (no more than $10 \%$ of the annual volume of their formation).

As part of natural and man-made formations that were formed under the influence of mining and mining industries, tailings dumps are represented separately. Technogenic deviations of the leading components in such formations significantly exceed the amplitude of natural vibrations. ${ }^{28-30}$

Tailing dumps belong to technogenic landscapes, which are designed as a dynamic element of natural and technogenic systems formed under the influence of the mining industry since the material stored and dumped in them is represented by a very small granulometric composition and is very easily transported by wind, exposing the adjacent territories to pollution, as well as this stored material by delivering it to the tailing dump by water removal, that is, in the form of water pulp, it is carried out using high-power bugger pumps. Thus, water is an integral component of any existing tailings storage facility.

A pond that is formed and exists permanently within the boundaries of regularly changing tailings on the surface, on the one hand, it covers and moistens a significant part of the tailings surface from enrichment, while preventing wind transport, and on the other hand, it intensively transfers the ingredients of the tailings of enrichment to the lower ground layers and underground water. This contributes to the process of local contamination of groundwater, as well as near rivers and reservoirs, which is confirmed by research data. ${ }^{31-51}$

The Balkhash tailing dump of the Balkhash processing plant (BPP) is of particularly great interest, as it is one of the oldest in the industry and one of the largest tailings dumps in Kazakhstan. In addition, it is not located in a simple arid zone, which in itself significantly increases the impact of the tailings dumps on the surrounding environment, it is located very close to lake Balkhash, which has a large, even huge economic purpose. ${ }^{52-55}$

The Balkhash processing plant, which owns the tailings dump, enriches copper-molybdenum ores from the Kounrad and Sayak deposits. The factory processes an average of 33,7 thousand tons of Kounrad and 9.5 thousand tons of Sayak ores per day. The enrichment waste is stored in the tailings storage facility.

In Kazakhstan, where 360-390 thousand tons of refined copper have produced annually, the amount of copper ore flotation waste is growing by 1.8-2 million tons per year, which hurts the environment not only of the urban landscape but also of the entire region. ${ }^{56-58}$

Thus, based on the current situation, when a huge amount of waste has accumulated in the Balkhash tailings storage facility over the decades of storage of enrichment tailings, which hurts the environment and human health. Tailings from enrichment at the moment still do not have technological methods and methods for their mass utilization. In this connection, we offer comprehensive processing of tailings from the Balkhash tailings storage facility, which contain such valuable components as oxides, silicon, aluminum, and iron, which automatically makes them an ideal raw material for obtaining cement clinker, and the presence of sulfides and zinc oxides contributes to the extraction of zinc by sublimating it with further capture.

Based on the conducted research, it was found that:

\section{CONCLUSION}

- Waste from copper ore processing continues to accumulate annually in the tailings storage of the Balkhash processing plant in the amount of 1,8-2 million tons, which have not found their application in the industry due to the complexity of their processing. all available technologies do 
not include mass processing of BPP tailings, but only partially use them, while their processing does not even reach $10 \%$.

- The chemical and mineralogical compositions of the tailings of the Balkhash processing plant are close to the compositions of materials used in the silicate industry, the presence of silicon, aluminum and iron oxides in the tailings of the enrichment is of scientific and economic interest.

\section{ACKNOWLEDGMENT}

This research was is funded research by the Science Committee of the Ministry of Education and Science of the Republic of Kazakhstan (Grant No. AP08053015)

\section{REFERENCES}

1. A. Zh Tishtykbaeva, T.A. Akanaeva, International Journal of Applied and Basic Research, 5, 454(2016)

2. A.A. Zharmenov, Complex Processing of Mineral Raw Materials in Kazakhstan, Folio, Astana, p.272 (2003)

3. T. M. Khudyakova, A. S. Kolesnikov et al., Refractories Industrial Ceramics, 60, 76(2019), DOI: 10.1007/s11148-019-00312-2

4. A.S. Kolesnikov, I. V. Sergeeva, N. E. Botabaev, A. Zh. Al'zhanova, Kh. A. Ashirbaev, Steel in Translation, 47, 605(2017), DOI:10.3103/S0967091217090078

5. A.S. Kolesnikov, et al., Rasayan Journal of Chemistry, 13(4), 2420(2020), DOI: $10.31788 /$ RJC.2020.1346102

6. A. Kairakbaev, E. Abdrakhimova, V. Abdrakhimov, Ecology and Industry of Russia, 6, 12(2019), DOI: $10.18412 / 1816-0395-2019-6-12-16$

7. A.S. Kolesnikov, G.S. Kenzhibaeva, N. E. Botabaev et al., Refractories and Industrial Ceramics, 3, 289(2020), DOI:10.1007/s11148-020-00474-4

8. A. B. Bayeshov, et al., News of the National Academy of Sciences of the Republic of KazakhstanSeries Chemistry and Technology, 6, 96(2018), DOI:10.32014/2018.2518-1491.31

9. Cadastre of Resources and Prospects for the Integrated Use of Waste From Non-ferrous Metallurgy in Kazakhstan, Almaty, p.12, (1988)

10. Cadastre of Resources and Prospects for the Integrated Use of Ores and Wastes of Ferrous Metallurgy, Almaty, p. 16, (1989)

11. Law of the Republic of Kazakhstan, On Subsoil and Subsoil Use, with amendments and additions as of 10.07.2012, p. 21, (2012)

12. https://kap.kz/file/2019/04/25/otchyot-kazniiek-2012-po-otkhodam-v-rk.pdf-.pdf

13. A.V. Malashta, N.A. Nuzhdina, V.I. Pavlova, I.V.Shadrunova, Mining Information and Analytical Bulletin (Scientific and Technical Journal), 12, 188(2005)

14. A.V. Nitsenko, S.A. Trebukhov, A.K. Kasymzhanova, N.M. Burabaeva, Inorganic Materials, 7, 621(2018), DOI: 10.1134/S0020168518070105

15. V.N. Volodin, S.A. Trebukhov, N.M. Burabaeva, A.V. Nitsenko, Russian Journal of Physical Chemistry A, 5, 800(2017), DOI:10.1134 / S0036024417050296

16. E.I.Kabanov, G.I.Korshunov, E.B.Gridina, Naukovyi Visnyk Natsionalnoho Hirnychoho Universytetu, 6, 117(2019), DOI:10.29202/nvngu/2019-6/17

17. S. Aisautova, Industry of Kazakhstan, 5, 62(2005)

18. S.N. Ajtekeeva, L.Ya. Agapova, E.I. Ponomareva, Z.S. Abisheva, Complex Use of Mineral Resources, 6, 27(2000)

19. Andrianov, I.K. International Science and Technology Conference "Eastconf", Vladivostok, Russia pp. 1-4(2019), DOI: 10.1109/FarEastCon.2019.8934017

20. K. Irshat, R. Petr, R. Irina, International Multi-Conference on Industrial Engineering and Modern Technologies (FarEastCon), Vladivostok, Russia pp.1-4. (2018), DOI: 10.1109/FarEastCon.2018.8602796 
RASĀYAN J. Chem.

Vol. 14 | No. 2 |997-1005| April - June | 2021

21. I. Romanova, IOP Conference Series: Materials Science and Engineering, pp. 032016(2018) DOI: $10.1088 / 1757-899 \mathrm{X} / 365 / 3 / 032016$

22. G.G. Chuyanov, Tailings and Wastewater Treatment, UGGGA, Yekaterinburg, p.246 (1998)

23. B.N. Laskorin, L.A. Barskiy, V.Z. Persits, Waste-free Technologies for Processing Mineral Raw Materials, Nedra, Moscow, p.334, (1984)

24. M.L. Shpirt, Waste-free Technologies Utilization of Wastes from the Extraction and Processing of Solid Fossil Fuels, Nedra, Moscow, p.254, (1986)

25. A.G. Khmelnitsky, Municipal and Industrial Waste: Methods of Neutralization and Recycling Analytical Reviews, Novosibirsk, Russia, pp. 231-236 (1995)

26. S.K. Mustafin, S.R. Kunakbaeva, Ecological and Geological Problems of Urbanized Territories. UGGGA, Yekaterinburg; 2006- C. 29-34.

27. O.S. Baigenzhenov, V.A. Kozlov, V.A. Luganov, R.A. Shayahmetova, I.O. Aimbetova, Mineral Processing and Extractive Metallurgy Review, 4, 242(2015), DOI:10.1080/08827508.2014.955610

28. A.S. Kolesnikov, Russian Journal of Non-Ferrous Metals, 55, 513(2014), DOI: $10.3103 /$ S1067821214060121

29. http://viewpointmining.com/article/a-benchmark-in-responsible-mining

30. M.A. Komarov, B.K. Mikhailov, Y.A. Kiperman et al., Technogenic Mineral Resources, MoscowAlmaty, p.268, (2003)

31. M.P. Vasilchuk, K.N. Trubetskoy, A.M. Ilyin, et. all, Mining Journal, 7, 1721(1995)

32. http://www.earthpapers.net/obosnovanie-i-razrabotka-effektivnyh-metodov-obogascheniyatekuschih-i-lezhalyh-hvostov-obogascheniya-rud-tsvetnyh-blagor

33. I.K. Andrianov, et. al., International Science and Technology Conference "Eastconf", Vladivostok, Russia pp.1-3 (2019), DOI:10.1109/EastConf.2019.8725322

34. Aigul Mamyrbekova, A. Mamitova, et al., Rasayan Journal of Chemistry, 3, 486(2016).

35. A. Vlasyuk, V. Zhukovskyy, N. Zhukovska, O. Pinchuk, and H. Rajab, WSEAS Transactions on Applied and Theoretical Mechanic, 15, 52(2020), DOI:10.37394/232011.2020.15.8

36. N.V. Vasilyeva, P.V. Ivanov. Journal of Physics: Conference Series 1354, p012065, 2019. DOI: $10.1088 / 1742-6596 / 1384 / 1 / 012065$

37. Aizhan Mamyrbekova, A.D. Mamitova, M.K. Kassymova, et al., Rasayan Journal of Chemistry, 13(4), 2332(2020), DOI: 10.31788/RJC.2020.1345761

38. S. D. Sokova, N. V. Smirnova. Journal of Physics: Conference Series: IOP Conf. Series, 012046, pp. 1-6 (2019), DOI:10.1088/1742-6596/1425/1/012046

39. A. P. Vlasyuk, N. A. Zhukovska, and V. V. Zhukovskyy, Mathematical Modeling and Computing, 1, 196(2020), DOI: 10.23939/mmc2020.01.196

40. Yu.E. Saet, B.A. Revich, E.P. Yanin et al., Geochemistry of the Environment, Nedra, Moscow, p.334, (1990)

41. Makhanbetov A.B., et al., News of the National Academy of Sciences of the Republic of KazakhstanSeries Chemistry and Technology, 6, 95(2020), DOI:10.32014/2020.2518-1491.103

42. I.K. Andrianov, International Science and Technology Conference "Eastconf", Vladivostok, Russia pp. 1-3. (2019), DOI:10.1109/FarEastCon.2019.8933949

43. A. Dzhangarov, M. Suleymanova, A. Zolkin. IOP Conference Series: Materials Science and Engineering, 862, 042046(2020), DOI:10.1088/1757-899X/862/4/042046

44. M. Kambatyrov, U. Nazarbek, P. Abdurazova, et al., Rasayan Journal of Chemistry, 13(3), 1308(2020), DOI: 10.31788/RJC.2020.1335729

45. I. A. Magomedov, A. M. Bagov, A. L. Zolkin. European Proceedings of Social \& Behavioural Sciences EpSBS, 90, 553(2020), DOI:10.15405/epsbs.2020.10.03.62

46. A. Boikov, R. Savelev, V. Payor, N. Vasileva, Journal of Physics: Conference Series, 1210, 012025 (2019), DOI: 10.1088/1742-6596/1210/1/012025

47. Y. Raiymbekov, U. Besterekov, U. Nazarbek, P. Abdurazova, Rasayan Journal of Chemistry, 1, 46(2021), DOI:10.31788/RJC.2021.1416080 
RASĀYAN J. Chem.

Vol. 14 | No. 2 |997-1005| April - June | 2021

48. I. A. Magomedov, H. A. Murzaev, A. L. Zolkin. European Proceedings of Social \& Behavioural Sciences EpSBS, 90, 1011(2020), DOI: 0.15405/epsbs.2020.10.03.117

49. N.V. Vasilyeva, P.V. Ivanov, Journal of Physics: Conference Series, 1210, p012158(2019) DOI: $10.1088 / 1742-6596 / 1210 / 1 / 012158$

50. A.S. Kolesnikov, Russian Journal of Non-Ferrous Metals, 56, 1(2015), DOI: $10.3103 / \mathrm{S} 1067821215010113$

51. S. D. Sokova, N. V. Smirnova. MATEC Web of Conferences: IPICSE-2018, pp. 1-10 (2018), DOI: $10.1051 / \mathrm{matec}$ conf $/ 201825106018$

52. A.I. Perelman, N.S. Kasymov, Landscape geochemistry, Astreya-2000, Moscow, p. 764, (1999)

53. A.V. Chigarkin, Regional geoecology of Kazakhstan, Kazak University, Almaty, p.224 (2000)

54. Zh. Aliyeva, et. all, International Multidisciplinary Scientific GeoConference: SGEM, Sofia, pp. 775782 (2019), DOI: 10.5593/sgem2019/5.2/S20.097

55. B.C. Cherednichenko, N. D. Storozhenko, A.G. Oleinikov et al. Hydrometeorology and ecology, 2, 192(1997)

56. Z.B. Karshigina, Ye.G. Bochevskaya et. all, Mineral Processing and Extractive Metal, 39, 319(2018), DOI:10.1080/08827508.2018.1434778

57. Zh. Aliyeva et. all, Geo Journal of Tourism and Geosites, 2, 460(2020), DOI:10.30892/gtg.29207-482

58. K.M. Dzhanaleeva, Anthropogenic Landscape Science, Kazak University, Almaty, p. 163 (2001)

[RJC-6229/2020] 